\title{
'Real people in real places': Conceptualizing power for emancipatory security through Tahrir
}

Security Dialogue 2015, Vol. 46(3) 272-290 (C) The Author(s) 2015

Reprints and permissions: sagepub.co.uk/journalsPermissions.nav DOI: $10.1177 / 0967010615575360$ sdi.sagepub.com

@SAGE

\author{
Ali Bilgic \\ Bilkent University, Turkey
}

\begin{abstract}
The objective of emancipatory security theory is to examine the insecurities of individuals and social groups that stem from oppressive power processes, relations, and structures. However, the image of power in emancipatory security studies does not correspond to such a normative and analytical motivation. This renders the theory susceptible to substantial criticism on the grounds of inadequate analysis of resisting individuals as agents of security in their own localities. To address this issue, the present article conceptualizes 'emancipatory power'. In this exercise, Hannah Arendt's understanding of power, enriched by Judith Butler's concept of performativity and feminist insights, will be used as the theoretical foundation to tailor collective power based on trust in a 'moment' of emancipation. Collective power will be illustrated by references to the protests in Cairo's Tahrir Square in $201 \mathrm{I}$.
\end{abstract}

\section{Keywords}

Emancipation, Hannah Arendt, power, security, Tahrir Square, trust

\section{Introduction}

Emancipatory security theory (also known as the Welsh School and the Aberystwyth School) developed under the umbrella of critical security studies and has always been motivated to unpack and explore myriad power-security relations. This is not only because the theory's analyticalpolitical objective is to examine the insecurities of individuals that stem from oppressive power processes, relations, and structures; it is mainly because these 'victims', whose choices are restricted by power structures, are regarded as agents for their own security (Booth, 2007: 226). Any theory of security without an approach to power (what power means, how it works, and to what end) remains analytically incomplete, as the politics of security is a power struggle (Roberts, 2012: 74). For emancipatory security theory, understanding the power of individuals who collectively resist oppressive power hierarchies is not simply an analytical question but also a normative 
motivation. However, the image of power in emancipatory security theory does not correspond to this motivation. This compromises the attempts to deliver the theory's main promise of studying the security of 'real people in real places' as emancipation (Booth, 2005: 275).

The focus on 'real people in real places' broadens the domain of security, as argued by scholars of emancipatory security theory and feminist security approaches. This broadening is performed through a focus on 'structural violence' inflicted on individuals through patriarchy, capitalism, militarism, and statism, in addition to 'physical violence' (Tickner, 1992; Booth, 2005, 2007). For feminists, the 'non-negotiable objective' of this practice is emancipation (Wibben, 2011: 591). According to the scholars of emancipatory security theory, security is emancipation and refers to the securing of people from structures, processes, and relations that prevent them from choosing 'what they would freely choose to do' (Booth, 2007: 112). This ostensibly liberal-rationalist and West-centric analytical move has attracted criticism, as will be seen later. To counter such criticism, emancipatory security can be rethought along the feminist line that introduces individuals' and social groups' own 'articulations of security' - that is, their own expressions of how security is understood by them (Hoogensen and Rottem, 2004: 155). Through the adoption of such an approach, individuals become the center of emancipatory security analysis as agents of their own security in their own cultural, historical, and political contexts. However, emancipatory security theory does not currently have an understanding of power that conceptualizes the power of individuals that are resisting structural and physical insecurities in the pursuit of security as emancipation.

This article discusses the power of resisting individuals as the ultimate referents and agents of emancipatory security. It aims to advance an understanding of power within the framework of emancipatory security for 'post-liberal' politics. In this light, the emancipatory power of resistance will be conceptualized as a productive power emerging during 'moments of emancipation', where individual subjectivities are reproduced within a collectivity based on trust. Emancipatory security is generated by individuals as agents of security through the formation of such a collectivity. In other words, emancipatory security emerges in the exercise of emancipatory power.

Booth (2007: 150) encourages security scholars to explore different types of politics that feed into contending understandings of security. Emancipatory security is derived from 'emancipatory politics' as a pursuit of human rights and freedoms with a strong focus on civil society as an emancipatory agent. However, this has led many scholars to associate emancipatory individual security with 'human security' and its liberal interventionist agenda. ${ }^{1}$ The present analysis makes the case for post-liberal politics as one from which emancipatory security can be derived. Inspired by Oliver Richmond and Roger Mac Ginty's idea of the post-liberal peace and by an Arendtian understanding of politics, post-liberal politics transcends the state, its narrow and exclusionary 'national' politics, and its ostensibly 'rational' actors and their interactions within bourgeois 'civil society'. Instead, it concerns innovative, pluralistic, and inclusionary political spaces in which individuals claim political agency through their 'everyday' practices (Richmond, 2010; Mac Ginty and Richmond, 2013). According to Richmond (2010: 670), 'the everyday is a space in which local individuals and communities live and develop political strategies [of resistance] in their local environment towards the state and towards international models of order'. Post-liberal politics rejects the self-other dichotomies of nationality, race, class, gender, and sex imposed on individuals by modern liberal politics, or by what Patricia Owens calls Arendtian 'what-ness'. In contrast, postliberal politics operates on someone's 'who-ness', which 'is their specific, unique, and distinguishing identity that is constantly recreated and revealed in political action and speech' (Owens, 2012: 556). When derived from post-liberal politics, the domain of security shifts from a realm of fear, threats, exclusion, control, and oppression to a realm of plurality and creativity. Thus, emancipation as security becomes a moment when individual political subjectivities are reproduced in a 
pluralist collectivity that transcends 'what-ness'. Redefining emancipatory security in this way necessitates delving into individuals' own articulations of security.

Prioritizing individuals' own articulations of security as the basis of emancipatory security requires a particular methodology that is offered by feminist security studies. For Hoogensen and Stuvøy (2006: 221), who put 'the everyday' - also a central focus of post-liberal politics - at the forefront, 'the way to understand and establish knowledge about security in empirical terms is to enter people's life-worlds'. Following in the steps of Maria Stern, the analysis set out in the present article accepts emancipatory security as a 'working modality of security' according to which (in)security can be detected. The contextualization of protests in Tahrir in 2011 in local political and economic processes will reveal that the protesters were subjected to physical (police brutality) and structural violence (such as poverty and patriarchy) by Egypt's Mubarak regime. Their security, however, is not predetermined by liberal politics. Instead, their 'security-as-emancipation' will be sought through the lifeworlds of the participants: How did they, as agents, pursue security in the 'everdayness' of Tahrir against the physical and structural violence inflicted by the regime? Security-as-emancipation is considered 'embedded in their representation of themselves as political subjects' (Stern, 2006: 183).

In their narrations about Tahrir, these individuals may not talk of security, but they talk about security. In such moments, emancipatory security gains a practical meaning through their ways of resistance to oppressive power relations and structures, leading to the main question of this analysis: How can we conceptualize the power of resisting individuals? In answer to this question, it must be noted that the analysis presented here does not aim to offer a blueprint for emancipation, security, and power in an ahistorical and non-contextual way. Such a blueprint would defy the main objective of this study, which is to bring the 'real people' in Tahrir into emancipatory security theory and highlight how even such a limited empirical practice can enable new openings for emancipatory security theory in rethinking power and emancipatory security.

The discussion begins with the examination of the existing power conceptualization in emancipatory security theory. The second section situates emancipatory power within the discussions of power in international relations. It argues that Foucauldian productive power is a power approach in which emancipatory power can be embedded. However, as feminists highlight, productive power also has setbacks, which will be addressed by introducing Hannah Arendt's understanding of power. Arendt's approach, enriched by Judith Butler's concept of performativity, not only facilitates a bridge between the individual and the collectivity in moments of resistance, but also paves the way for introducing trust into emancipatory power. This will be performed in the third section. Finally, emancipatory power, along with new articulations of emancipatory security, will be illustrated through the narrations of individuals. This illustration will focus specifically on the first week of protests in Tahrir Square, Cairo, in January 2011.

\section{Emancipatory security theory's power problematique}

Since the conceptualization of 'security as emancipation' by Booth (1991), criticism of emancipatory security theory within critical security studies has revolved around three main themes. The first concerns the inability of emancipatory security theory to acknowledge and challenge political and epistemological practices that operationalize emancipation as a way to 'save' others (Dunne and Wheeler, 2004) or 'educate' peoples for their own emancipation (Wyn Jones, 1999: 160-162). Therefore, emancipation-as-security becomes an ideological mechanism that exerts social power, which in turn reproduces individual subjectivities and communal identities from the perspective of the liberal, Western, male protector/savior. The resulting implication is the reconstruction of neoliberal, West-centric, and gendered global structures and relations (Duffield, 2010; Neal, 2010; 
True, 2011). The second line of criticism originates from the scant analytical focus on resistance to oppression, especially when resistance takes a violent form with the purpose of 'emancipation' (van Munster, 2008; Peoples, 2011). It is indeed surprising that a security theory that prioritizes resisting individuals as agents of emancipatory transformation does not offer a satisfactory theoretical and empirical account of resistance and violence. Third, scholars of critical approaches to security challenge emancipatory security theory because it neglects the oppressive dimension of security. This contravenes the logic of emancipation (Aradau, 2008; Neocleous, 2008) and hinders the possibility of studying resistance (Aradau, 2004: 397). This criticism rightly questions the equation of emancipation with security in emancipatory security theory without a consideration of how the concept of security is used for control and oppression in liberal governmentality.

Emancipatory security theory's limited power conceptualization and ostensibly liberal definition of 'emancipation' render the theory vulnerable to the aforementioned criticisms primarily because emancipatory security theorists have not adequately integrated into their analysis resisting individuals in their own localities as agents of security (contra Booth, 2011; see McDonald, 2012; Bilgic, 2013). The alternative 'bottom-up' security notions (Mac Ginty, 2010), experiences, and subjectivities of such individuals have been overlooked or simply rhetorically acknowledged without a proper consideration of local agents' security practices, while the type of power that individuals perform to render themselves agents of their own security has not been conceptualized. This results in analytical and normative problems, as emancipatory security theory remains underequipped to respond to the criticisms outlined above (see also Hynek and Chandler, 2013: 54-56). Thus, the question arises: Where does the power of resisting individuals who pursue security lie? Emancipatory security theory identifies three approaches for addressing this question. ${ }^{2}$

Booth's approach highlights an uneasy understanding of power. While power is assumed to be a political force that dominates, oppresses, and corrupts, the approach is also normatively motivated by the objective to 'empower' individuals with the purpose of emancipation. In his early writings, Booth (2000: 54) attempted to solve this dilemma by prioritizing the immaterial dimension of power over its material dimension and by denouncing material power. In his later writings, he praised Foucault's exposition of the power/knowledge nexus, while at the same time raising criticisms of the approach. For Booth, the Foucauldian approach reduces all knowledge and truth to power. Calling for a counter-concept to power, he argued that 'the knowledge/power relationship is one reason why we need a concept of truth [that is, emancipation], for without it power is the only arbiter' (Booth, 2007: 242). On the one hand, Booth understands power as an oppressive material and immaterial phenomenon that can victimize and silence particular groups of individuals. His rejection of the reduction of knowledge and truth to power is underlined by the concern that if claims to knowledge and truth are understood through oppressive and dominating power, the weak can be further silenced and disempowered. On the other hand, since he endorses the relationship between power and knowledge, students of emancipatory security theory are encouraged to generate knowledge to 'give voice to the voiceless', and therefore to empower them (Booth, 2007: 242). However, there is no explanation of how empowerment can be thought and practiced without a concept of power that is compatible with emancipatory politics.

Fierke offers a more practical framework of emancipation, one that is underlined by an alternative conceptualization of power. This power refers to the individual's ability to realize his or her ends in spite of oppression. Fierke's alternative power does not stem from fear, control, and domination. Instead, power is 'to stand tall, with dignity, even though one is weak' (Fierke, 1998: 97). Although Fierke's approach to the power of the 'weak' and resistance provides a more practical account than Booth's, it also has shortcomings. First, power is taken for granted as an individual property that stems from the individual's legitimate and rightful normative position (e.g. antiracism in the case of the civil rights movement). Second, the thread linking individual 
empowerment (such as that of Rosa Parks) and the power of collective resistance (e.g. social movements towards the end of the Cold War, such as Solidarity in Poland) is not well developed. However, understanding power solely as an individual property cannot generate collective resistance, nor can it challenge oppression. What is needed is a power understanding that explores the emergence of power through individual social practices, as well as its effect on individuals and collectivities.

The social and dynamic understanding of power is most effectively and explicitly introduced to emancipatory security theory by Nunes' (2012) study, which integrates Foucauldian power into the theory. Advancing the criticism that the governmentality of various forms of security has reproductive and controlling effects on individual subjectivities (Aradau, 2004, 2008; Roberts, 2012; Richmond, 2011a), Nunes' analysis is underlined by the concern that emancipatory security theory does not sufficiently consider the 'materializing' effects of oppressive security practices and structures on individuals. This raises a question for emancipatory security theory: it is not clear ' $w$ hat one is to be emancipated from' (Nunes, 2012: 353, emphasis in original). For Nunes, the way to address this deficiency is to integrate a Foucauldian account of power into a more insightful explanation of how power works in the politics of security. As a result, he discusses how power produces subjects in governmentality, rather than dominating them. By integrating 'productive power', Nunes argues that emancipatory security theory might be better equipped to examine the effects of security practices in the (re)production of individual subjectivities that, in turn, reinforce existing security practices. Understanding the relationship between how individuals produce power and how power produces individuals is essential for emancipatory security theory. That said, this Foucauldian approach can contradict emancipatory security theory, as will be discussed next.

\section{Thinking productive power for emancipatory security: An 'Arendtian corrective'}

Within the discipline of international relations, the mainstream understanding of power is that actors exercise power over others either through direct coercion, using institutions and structures (Holsti, 1964; Schmidt, 2005; Rosecrance, 2006), or through persuasion (Nye, 2004; Lebow, 2005; Lukes, 2005; Van Ham, 2010). Until recently, the discussion centered on how one can exercise power-over others in order to increase power-to (Hearn, 2012: 7). An alternative approach asks 'What does power do?'. It investigates performances of power in micro- and macropolitics, along with the effects of power on those who exercise power and on those upon whom power is exercised (Guzzini, 2005: 508). This corresponds to 'productive power' in Barnett and Duvall's (2005: 1322) typology of power. Productive power unfolds relations of power by revealing how performances constitute individual subjectivities as subject and object positions in these relations (Bailey, 1993: 116-117). It also offers a critical prism to study power from the perspective of objects of power, who produce power through their performances (Shepherd, 2010: 6; Fraser, 1989: 18; see also Butler, 1990). Several critical studies examine these processes (Muppidi, 2005; Agathangelou and Ling, 2005; Amigot and Pujal, 2009; Shepherd, 2010; Bigo, 2011). Nunes' focus on the materializing effects that security practices have on the reproduction of individual subjectivities is similar to this critical practice and potentially results in a better grasp of how power works in the formation of competing security claims of individuals (Nunes, 2012: 354-355).

Although productive power offers a dynamic, relational, social, and critical perspective, it also has several shortcomings that hinder Nunes' attempt to secure wholesale acceptance of the concept within emancipatory security theory. The first concerns insufficient attention to the power of resistance - in other words, the power of 'docile bodies'. Feminists who use a Foucauldian approach not 
only analyze how female bodies are formed in docility and obedience through power, but also how they can find spaces of resistance (see, inter alia, Bordo, 1993a, 1993b; Amigot and Pujal, 2009: 652). This leads Allen (1999: 55) to argue that Foucault's power suffers from 'the paradox of agency': individuals are accepted as subjects who have agency (an ability to act and resist), yet this agency is taken away when a deterministic account of human actions as subjected to power is accepted. Second, feminists raise the problem of normativity in Foucault's analysis. Although Foucault (1980: 785) criticizes oppressive power relations and calls for resistance to an individuality 'which has been imposed on us for several centuries', many feminists have been critical of Foucault because he overlooks normative distinctions between different uses of power (Fraser, 1989: 32; McNay, 1992: 141). The last setback is related to power stemming from collective action. Foucault rejects the idea of power based on concert, unlike Arendt below. This 'commits Foucault to a wholesale rejection of any sort of understanding of power that is generated through reciprocal, collective social action' (Allen, 1999: 56).

Productive power's dynamic and social approach, which focuses on performances, renders it a conceptual backdrop against which emancipatory power can be conceptualized. That said, feminist criticisms of Foucault are useful in terms of indicating how Foucauldian power in emancipatory security theory is incomplete because of its limited account of resisting agency and its power. By bringing productive power and resisting agency together, emancipatory power is generated through performances of individuals who resist and reject the objectification of coercive (as in physical) and structural power relations that give rise to physical and structural insecurities. It produces a new type of subjectivity that is defined in relation to a collectivity. It also analytically and normatively illuminates the ways in which individuals, in spite of their docility, can resist oppression in solidarity. To substantiate this, Hannah Arendt's political philosophy is introduced.

Owens (2007: 14) describes Arendt's political philosophy as challenging the approach that automatically equates violence with power, thereby 'end[ing] the modern fascination with reducing politics to violent domination'. She argues that Arendt puts human plurality, with all its disagreements and differences, 'at the heart of politics', where individuals as plural equals bestowed with thinking and natality (capacity to create anew) come together to resist the old systems and to create new spaces of freedom (Owens, 2007: 30-31). Therefore, according to Arendt, power, freedom, and politics are interwoven in a way that can articulate the resistance of individuals in the language of power. Power 'corresponds to the human ability not just to act, but to act in concert. Power is never a property of an individual; it belongs to a group, and remains in existence as long as the group keeps together' (Arendt, 1970: 44) in what Arendt terms 'the space of appearance'. This is generated by individual performances and, in turn, reproduces subjectivities. However, it is not oppressing or dominating. Rather, it stems from the plurality of individuals who think and create anew.

In order to explain why Arendt conceptualizes power as the potential of individuals for collective action, two key concepts of Arendt's understanding of individuals should be stressed. The first concept is thinking: 'the effort to undo systems by continuous questioning' and 'empathy', the effort to understand others without losing one's self (Kateb, 2010: 36-38). The second concept is natality, which refers to 'the capacity [of individuals] of beginning something anew, that is, of acting' (Arendt, 1998: 9). Natality points to the potential of individuals to take social initiative and start something new 'as a second birth' through speech and action (Gordon, 2002: 139). Each human being has 'the capacity to initiate a new set of words and actions that are uniquely hers and ... no human life can ever be the replica of any other' (Benhabib, 2010: 5). As a result, when these individuals form a body politic, it transcends what-ness in favor of individuals' 'who-ness'. Whoness will contribute to the rethinking of emancipatory security in the case of Tahrir as individuals exercise their collective power. 
It is not possible to overlook the modern politics that target and shape subjectivities (and bodies) of individuals, who in return reproduce existing relations and structures through their performances. However, it is also not possible to reduce the 'human condition' to processes of normalization and control. Indeed, Foucault and Arendt share various principles of modern politics and political philosophy: the rejection of ahistorical and asocial subjects, the 'normalizing' effects of modern political practices on individuals, and, most importantly for the purposes of this analysis, the acknowledgement of resistance (Dolan, 2005). However, while Foucault posits resistance against the normalizing, controlling, and yet productive power, Arendt seeks power in 'the potential that enables humans to break away, or more precisely, to disrupt the hold of Foucauldian power' (Gordon, 2002: 134). This renders Arendt's power a suitable framework for defining emancipatory security. Thinking and natality construct individuals as agents who reflect upon systems and launch initiatives to create anew. Arendt's political philosophy powerfully shapes Allen's concept of feminist power-with, which refers to 'a collective ability that results from the receptivity and reciprocity that characterize the relations among individual members of the collectivity' (Allen, 1999: 126). Power hereby does not take the form of limiting the choices of others, nor does it stem solely from individual empowerment and resistance. It is derived from solidarity among those who are victimized by oppressive power. Power-with emerges from collective action and transforms subjectivities. This is a productive power that is generated by and generates not Foucault's 'docile bodies', but Arendt's individuals who think, create, and resist together. In its ephemerality and temporality, emancipatory security can be realized in the process of exercising this collective power.

While Arendtian power-with provides us with the theoretical and normative perspective to conceptualize power for emancipatory security, it also has two setbacks, underlined by Butler (2011). First, the Arendtian approach does not focus on the materiality of the 'space of appearance'. Second, it potentially excludes what is assumed as pre-political and private from the space of appearance. This can result in a reproduction of inside/outside, inclusion/exclusion, us/them dichotomies. To address these problems, Butler argues that bodies gathering together in plurality reconfigure the material space that in turn supports the resistance. In addition, 'the everyday' in the reconfigured material space renders the resistance popular by encouraging more people to join. These issues will be revisited in the case of Tahrir.

In spite of its limitations, Arendtian power-with provides fundamental advantages to the conceptualization of emancipatory power. Thinking in terms of reflexivity and natality enables the agency of individuals to resist what they think is oppressive. Therefore, individuals' localities, needs, and requirements can be situated at the center of emancipatory security analysis in tandem with their ways of pursuing security. Furthermore, for emancipatory security theory, the 'space of appearance' paves the way for exploring spaces that are constructed politically as alternatives to narrow state-level politics. In post-liberal politics, squares, streets, and parks are constructed as spaces of resistance where individuals pursue security by challenging oppression through their bodily performances, as Butler (2011) rightly argues. Emancipatory security, therefore, does not simply revolve around the transformation of 'non-liberal' structures, but emerges as the reproduction of resisting individuals' subjectivities in the pluralist space of appearance. Finally, powerwith links the individual to a collectivity in which pluralism triumphs over homogeneity. Since this collectivity is formed on the basis of individuals' who-ness rather than their what-ness, it is inclusionary and upholds differences, thus giving a practical meaning to emancipatory security. 'The everyday' is practiced collectively in the space of appearance; this collective dimension is fundamental for emancipatory power. Next I discuss how this collective body can be constructed through trust. 


\section{Emancipatory power-with through trust}

Power is actualized in a body politic when members of the group believe that other members will keep the promises that brought them together: 'sovereignty of a body of people bound and kept together, not by an identical will which somehow magically inspires them all, but by an agreed purpose for which alone the promises are valid and binding' (Arendt, 1998: 245). The body politic, because of the power-over of sovereignty, is not a realm of uncertainty due to domination and sometimes violence. However, in Arendtian thinking, power and uncertainty go hand in hand, because power depends on keeping mutual promises in the collectivity (Arendt, 1998: 244). This is where we need to explore the relation between trust and power-with.

Trust can be defined as one's belief that he or she will protect and promote others' interests with the expectation that others will act in a similar way (Booth and Wheeler, 2008: 230). Furthering of interests (both narrow and broad) is essential for any definition of trust. One group of scholars argues that trust appears when 'rational' actors cooperate with each other with the expectation of gaining benefits from the cooperation. This is identified as 'cognitive trust', where the trusting parties rationally make calculations about each other while monitoring each other's behaviors (O'Neill, 2002: 64; Nielsen, 2011: 162). The second social approach is 'affect-based trust', which is the belief that 'the goodwill and competence' of another will honor the interaction; in other words, the expectation that the trustee will be 'moved by the thought that we are counting on her' (Jones, 1998: 4; Hoffmann, 2006). Trust has a social dimension whose source lies in social norms and moral qualities. These norms and moral qualities construct a 'bond' between individuals. Therefore, trust becomes an expectation that others will honor this bond and 'do what is right' (Hollis, 1998: 10-13). Booth and Wheeler (2008: 238) conceptualize empathy as a property of social trust that enables bonding: a shared we-feeling among trusting parties.

Notwithstanding their pioneer role in integrating trust into the politics of security, the current studies have an important setback: they dichotomize the social/moral and the rationalist dimensions of trust. However, as Dietz (2011: 215) argues, 'there is always an assessment (however thorough) of the other party's trustworthiness', as it is unlikely that any individual makes him- or herself vulnerable without considering self-interest. In contrast to the aforementioned studies, an alternative approach argues that a trust relationship cannot be reduced to rational self-interest calculations or to making oneself vulnerable in order to honor the moral bond with another (Ruzicka and Wheeler, 2010; Bilgic, 2013). Social trust can have a 'calculative antecedent', where the parties evaluate what they can self-centrically obtain from the relationship (Cohen, 2014). They monitor the other party's practices and even take self-protective measures. Even if the trust relationship is primarily motivated by self-interest, the performances of actors can transform parties' interests towards the construction of a common identity (Wendt, 1999: 147-157). Following this perspective, one can argue that even if actors start a trust relationship for purposes of self-interest, it can potentially evolve into a deeper trust relationship. In other words, cognitive trust can lead to affectbased trust (Nielsen, 2011: 162).

Trust is necessary for the actualization of emancipatory productive power-with for three reasons. First, trust is a practice of Arendt's reflexive individuals. Trust cannot be imposed on individuals; instead, they choose to trust each other by acknowledging both their own and the other's agency (Seligman, 2000). This choice can be initially made to further self-interests against a common enemy (such as an authoritarian regime). It can also evolve into a social-trust relationship among previously socially and politically estranged individuals. Second, in post-liberal collective resistance, the factor that holds the resisting collectivity together is social trust and not a shared ideology, religion, nation, and class - or not 'what-ness'. Since the 'we-feeling' is not provided by an exclusively defined communal identity, it allows pluralism and coexistence of differences; 
through trust an individual is linked to a community. As a result, Arendt's space of appearance is reconstructed as a space of resistance among trusting individuals, transcending the liberal model's narrow politics. Third, social trust is generated by bodily 'everyday', nonviolent performances of individuals, such as Christians forming a protective wall around the praying Muslims in Tahrir. 'The everyday' becomes a focal point where the resistance is kept together, as trust is reproduced through 'the everyday' in the space of appearance. Empathy, as the 'identification with victims of oppression' (Confortini, 2012: 28) that develops between trusting individuals, is crucial to constructing a shared we-feeling.

The conceptualization of emancipatory collective power as ephemeral (which is the exact opposite of violence for Arendt) is crucial in order to avoid its reification, institutionalization, and possible reproduction as oppressive power-over individuals. This requires a new understanding of emancipation, which is developed by Basu in the idea of the 'emancipatory moment'. 'Moments pass, actors and context change, and any security practice identified as such has to re-evaluate its vision for transformations accordingly, in the quest for emancipation' (Basu, 2012: 106). As emancipation becomes momentary, emancipatory power can be understood as a temporal, fluid, and ephemeral power-with enabled through trust. It stems from the temporal collective actions of individuals, who share a we-feeling without imposing a dominating group identity - including the Western liberal one - that subjugates differences and disregards local contexts. Its objective is to enable a community of individuals to be referents and agents of security. In an emancipatory moment, the material space is reconfigured through the bodily performances of individuals in their own localities. When they build trust between each other through their performances, they exist in the 'space of appearance' together, which is the manifestation of their emancipatory power.

If the liberal approach to emancipation is dropped in favor of a spatio-temperal and ephemeral one, it is possible to differentiate collective emancipatory power from other types of power. First, emancipatory power is defined as the power of those individuals who are subjected to domination by coercive, institutional, and structural powers that produce 'life-shattering experiences' or insecurities (Agathangelou and Soguk, 2013: 3). Insecurity can be physical as a result of the coercive power of the state, as in the case of police brutality, or structural, as in the cases of poverty and patriarchy. These insecurities provoke individuals to form resistance together and intervene in the status quo by reproducing individual subjectivities in a collectivity through trust, transcending identitarian dichotomies. Second, emancipatory power does not generate coercive, institutional, and structural power-over. Resistance in the post-liberal world is not about violent coercion or persuasion to construct structures that dominate others (Richmond, 2011b: 421). Emancipatory power of resistance does not reproduce the insecurities that it aims to address. Instead, it facilitates security through the reproduction of subjectivities in a collectivity of pluralism and natality without generating insecurity (physical or structural) for the members and non-members of the collectivity.

A conceptualization of 'emancipatory power' aims to advance the developing discussion about emancipatory security theory in three ways. First, it opens up the security analysis to infinite possibilities that focus on individual critical agency. Emancipatory security theory set out to pluralize the politics of security by integrating alternative notions of security (Browning and McDonald, 2013; McDonald, 2012). These alternative notions are to be found in resisting individuals' experiences, 'the bottom-up' (Hoogensen and Stuvøy, 2006). Kaltofen (2013: 44-45) argues that if security is articulated in terms of 'the ineffable', it becomes possible to integrate individuals' experiences of in/security into the analysis, which 'restores individual human agency'. As a result, infinite possibilities exercised by Butler's 'bodies in alliance' can challenge the idea that security and oppression are inherently linked. Second, emancipatory power reveals how emancipatory security can work in practice as moments of reproduction of individual political subjectivities in a 
collectivity while maintaining their differences. Emancipatory power cannot emerge when the individual is singled out from a collectivity. It is a result of a local collective action, in contrast to the Western liberal individual's self-realization. Finally, this analysis addresses the criticisms about violence and emancipation (Peoples, 2011) by showing that emancipatory power is an opposite of violence. A moment of emancipatory security in Cairo's Tahrir Square in 2011 will illustrate how emancipatory power operates in practice in post-liberal politics.

\section{An 'emancipatory security moment' in Tahrir: Power-with through trust}

Built in the 19th century and used by a series of oppressive regimes as the embodiment of authority and political power, in early 2011 Tahrir Square was reconfigured as a space of appearance, an alternative political space in which individuals collectively resisted domestic and international power hierarchies. The events from 25 January to 2 February 2011 were an abrogation of 'the modern' and an example of collective resistance in the post-liberal world. In Tahrir, individuals who were not united by a common ideology, nation, religion, or class (their what-ness) formed 'a functioning social universe, a temporal community', where the extraordinary met 'the everyday' (Rashed, 2011: 22; Mellor, 2014). In that 'moment of emancipation', cognitive trust evolved into social trust through the everyday bodily practices of individuals. While physical security was temporarily achieved in the new political space, structurally created self/other dichotomies between genders, classes, and religions were transcended through the reproduction of individual subjectivities as members of a resisting collectivity. This was emancipatory security that emerged through the exercise of emancipatory power. Resisting individuals as agents of security generated and experienced an emancipation that exceeded the narrow, Western, liberal one. The following discussion thus brings both 'people' and 'places' into the emancipatory security analysis.

Mass protests form an integral part of Egypt's political history. Although such protests sometimes produced limited political reforms (such as those in 1968), they generally resulted in more oppression of the opposition in the name of protecting 'stability', a catchword of Mubarak's regime (Cook, 2012: 101-105, 274). Nevertheless, since the early 2000s, protests started to politicize the wider public. This gave rise to new resistance movements, such as the Popular Committee in Solidarity with the Intifada in 2001 and the Kifaya (Enough!) in 2004, which opposed the Mubarak regime and brought ideologically different opposition groups together (Hirschkind, 2012: 922). Protests by structurally disadvantaged groups were revitalized in the April 2008 'bread strikes', mainly organized by workers from the textile industry and joined by students. In June 2010, there were protests about the murder of blogger Khalid Said. Members of the middle class were subjected to police brutality, which, in their own words, was previously targeting 'only members of lower classes and the Muslim Brotherhood' (Bauer and Schweitzer, 2012: 4). As a result, trade unions and other labor organizations joined by students and members of the middle class became stronger and emerged as important groups in the 2011 protests (Teti, 2012: 273275). In addition, women, who had been subjected to gendered violence by the 'hypermasculinized' regime of Mubarak, invoked their agency to resist in Tahrir (Johansson-Nogués, 2013) for their own security.

During the Mubarak regime, urban planning was used in combination with a series of Emergency Laws in an attempt to depoliticize public spaces such as squares (Gregory, 2013: 239). While the pre-January 2011 protests repoliticized and reconfigured Cairo's urban space as a space of resistance, January 2011 was a political project whose management had been planned in advance. Starting from 2006, 'the Academy of Change', a civil activist group of Egyptians in the UK, collected texts about nonviolent protests, which were widely circulated in Egypt (Bauer and 
Schweitzer, 2012: 9; Rosenberg, 2011). In the months leading up to January, activists adopted three methods that reveal 'discontinuity with past strategies of resistance: maximum secrecy, new tactics for mobilizing common people and the adoption of a different rhetoric' (Trombetta, 2013: 140). Alaa Abd El-Fattah, a leading activist, stated that the real difficulty before the protests was not gathering liberals, Islamists, and leftists, but getting 'the people who do not identify themselves with any of these labels' to join the protests (Hirschkind, 2012: 922). The tactics appealed to the low-economic-status groups that were primarily created by Enver Sedat's liberal economic turn (Cook, 2012: 273). The new nonviolent tactics rendered the January protests possible. However, Tahrir's reconstruction as a politicized space of appearance where individuals resist collectively was achieved through trust built by 'the everyday' during an extraordinary mass movement. Local individuals' bodily performances became 'performances of space' (Gregory, 2013: 235; Butler, 2011) through which emancipatory security gained new local, contextual, and political meanings in Tahrir.

Despite long-term preparations, Tahrir's temporal community did not emerge immediately. Imposing certain dichotomist identities (what-ness), Mubarak's regime undermined a sense of community in Egypt and divided people along religious and class lines (Cook, 2012: 275). In the beginning, negative preconceptions prevented some protesters from sharing a we-feeling with others. What connected them, but did not unite them, was their resistance against the coercive powerover of the authoritarian regime. The following reflection of a feminist activist on other female protesters belonging to the Muslim Brotherhood illustrates this:

There would be a group of women - whom I would have once avoided and labeled them as Muslim Brotherhood - walking in a group around the Square with strength and vitality calling for the downfall of the regime. I joined them as they passed beside me in the sea of people in the square. Remembering the protests of students who called themselves the youth of the Muslim Brotherhood and how the young women would walk silently after the men, I would be infuriated (quoted in Magdy, 2011).

However, under the condition of physical insecurity experienced by the protestors as they were targeted by the police, their trust relationship started to improve. Bodies of individuals from different sociopolitical and economic backgrounds stood up together against the security forces, and empathy appeared. Although surprising in the beginning, the idea that the protesters could trust each other by building a we-feeling began to emerge:

The first time I was in Tahrir in the middle of the waves of people I was about to be trampled on, and suddenly this guy standing beside me lifted me and put me on the curb we were standing next to so I would be a bit higher. I don't remember his face. What I remember was that I wasn't scared, or straining my brain to react fast. My sister got on the curb beside me and a woman whom I personally would never have thought I would accept - or she would accept me - put her arm around my sister's shoulders, hugging her, embracing her warmly, as we all stood there chanting and singing. Friends who witnessed one attempt at harassment at the Square told me how everyone taught the guy a lesson he wouldn't forget any time soon (quoted in Magdy, 2011).

What once was a loose gathering of individuals against the regime started to become a community of individuals, a body politic where each individual's who-ness united him or her with others. Resistance against the physical violence of the police, the regime's thugs, and sexual assaulters offered one dimension of emancipatory security in Tahrir's collectivity. 'The everyday' bodily performances of individuals deepened trust among them. This restored the sense of community of individuals, leading to another dimension of emancipatory security as the protestors exercised collective power. One participant stated: 
During the demonstrations I have seen surprising things: I discovered the huge generosity of Egypt's people. I saw, for example, a guy who loaded his motorcycle with baskets of bread for the demonstrators. Other people came with bags full of taameya and koshari sandwiches. A guy carried boxes of bottled water. Cigarettes were passed hand to hand. And the most impressive thing: people picked up both their own and other people's garbage. Everything was organized so quickly. This is an Egypt I haven't seen before, and it's so beautiful to see This is the first time I have seen a united people sharing food, water, and opinion, despite their differences (quoted in Sampsonia Way, 2011).

Moving away from physical security, this statement showed that security was about becoming one with others 'despite their differences', and about transcending dichotomist identities through 'the everyday' bodily performances. Tahrir's materiality was reconfigured on two levels. While the edges of the square were protected by the football-club fans and members of the Muslim Brotherhood - two of the most resilient groups against police brutality - the center was hosting a society where 'the everyday' bodily performances were building social trust between the protesters, each of which seemed to honor the moral bond. Bodily performances were sometimes extraordinary, as when Christians set up a human wall to protect the praying Muslims. Performances sometimes reflected 'the everyday', such as teachers opening a kindergarten for protesters' children (World Peace Through Technology, 2011). Another protester reflected:

Amid continuous, often creative chanting, young men and women are going around collecting rubbish, one of them telling me 'this is our square, our home, we must keep it clean'. People are forming neat queues - something Egyptians never do - to buy tea at improvised stalls. Everywhere everyone is on their best behaviour; a few days later, women will tell me that sexual harassment, an endemic problem in Cairo, is absent from the square (quoted in Rashed, 2011: 25).

The everydayness of Tahrir attracted more people to protest while blurring the boundaries between 'us' and 'them', inclusion and exclusion (Rashed, 2011:26) in the moment of emancipatory security when the collective power was experienced. According to one protester, 'the everyday' in Tahrir became a tool that attracted more people to join:

When people came to the square, they weren't just protesting against the Mubarak regime. They immediately became involved in the clean-up crew, or with the sign painters, or setting up tents, or on a security detail. Many people who were not affiliated with any party or association joined us in this way (quoted in Hirschkind, 2012: 922).

The everydayness of Tahrir also proved to the Egyptians that there were no 'foreign' powers behind the protests, only regular people like themselves (Rashed, 2011: 26). The bodily performances of individuals reconstructed Tahrir as a 'home', a secure political space. Their subjectivities were reproduced in a pluralist, local collectivity. In the process, initial cognitive trust evolved into social trust through 'the everyday'. The same feminist activist who had been suspicious towards Islamist female protesters stated:

Now, these women I joined and others are making history, shouting and singing and sending out trills of joy without thinking that a woman's voice shouldn't be heard. This revolution proved that Egyptian women have a voice which they aren't afraid to use (quoted in Magdy, 2011).

Transcending dichotomist identities, the above participant became an agent of her security by claiming her voice through shouting and singing with others who were different. In a moment of emancipation, the body politic in Tahrir showed that power can result from a shared we-feeling, 
which is not necessarily dominating and hegemonic but allows differences and pluralism in an Arendtian space of appearance. This collective feeling was pluralistic, open to differences, inclusive, and physically secure. A feminist activist's reflection on the movement in Tahrir is useful to make this point:

During the weeks Egyptians have spent in Tahrir square, we have come to see another side of us as a people. In Tahrir square there was no harassment, there was no division in religion, age, social status, educational status or gender.... Women were side by side with the men and no one stopped to question someone's gender. There was something bigger holding the people together. Personally, I was always apprehensive about walking in the streets. The possibility of someone grabbing you or maybe worse was on my mind all the time (quoted in Magdy, 2011).

A protester, Muhammed Ramadan, tells of the plurality of the body politic bound by a common we-feeling by stating that 'in my whole life I'd never seen protests like that. Girls! Some wore hijabs, some didn't, Christians, Muslims - I'd never seen that' (quoted in Anderson, 2011). Therefore, individuals with their pluralism and natality, coexisting as agents of security against physical and structural violence, became a practical manifestation of emancipatory security. Another protester concurs that 'I saw all these different and surprising kinds of people protesting and thought, wow, this can happen' (quoted in Anderson, 2011).

Trust offered them a motivation to carry on even when the collective resistance was under attack by the police and pro-Mubarak militia (Khalil, 2011: 219-230). The words of Khalid Abdalla, an Egyptian actor and activist, provide the most illuminating expression of how trust enabled individual protesters to continue their protests thanks to the (elusive) certainty that trust offers:

When you know there are thousands upon thousands upon thousands behind you, you don't stop.... It's a matter of - it's how, kind of, consensus expresses itself as a movement. And essentially, your heart takes over your body. It takes over your mind. We're fighting for things far bigger than this (quoted in Citizen Action Monitor, 2011).

The reflection of a female protester, Marwa Faroak, showed how subtle the trust relationship in Tahrir was: 'One of the things that gave me an incredible sense of wonder was how safe I felt.... Tahrir Square became safer than anywhere else for a woman to be (quoted in Lally, 2011). For some women, trust between individuals sharing we-feeling in Tahrir was an empowering experience. This is a manifestation of how power-with can feed into power-to. Mona Ahmed Saif, blogger and activist, said:

I felt accepted and welcome for the first time by young men in my country. They treated me as a peer, and it was great getting into political discussions with random guys in Tahrir square feeling completely at ease and safe.

Emancipatory power empowered Mona to pursue her own security, which means being treated equally by the men in political discussions challenging patriarchal politics. Mona said that the experience in Tahrir changed her: 'It changed how I see myself among a crowd in the streets of Cairo. It changed my body language in public. I became stronger and more confident while dealing with others.... I walk around alone late at night feeling safe. I haven't had a single sexual harassment incident' (quoted in Magdy, 2011). In a moment of emancipation in Tahrir in 2011, individuals were able to develop a trust relationship without giving up their differences. They reconstructed Tahrir as a material space of appearance and acted collectively in solidarity. Their power emerged through the bodily performances of individuals in concert; in return, it produced subjectivities. As 
trust enabled the presence of the group, emancipatory power-with with its ephemerality appeared in Tahrir. It lasted for a moment, and its end calls for a new moment, given the post-Tahrir period.

In this moment, individuals became the agents of their own security, both physically by creating a secure space and structurally by defying identitarian dichotomies. However, this does not mean that insecurity was absent. As stated earlier, while the center of Tahrir was a realm of individual security within a collectivity, the edges were violent and physical insecurity was high, especially when the regime-supported Bataliyya troops attacked the collectivity. These borders, however, were not closed to those who chose to join the collectivity. Furthermore, sexual assaults started when the collectivity was gradually dissolving after 2 February, and has since become one of the most important insecurities women face in Egypt today (see Tadros, 2013). However, none of these cases write off the fact that individuals, including women, became agents of their own security during the first week by resisting in a collectivity. In fact, the emergence of this insecurity during the dissolution of Tahrir underlined the importance of the collectivity for security. Moreover, some Egyptian feminists argued that Tahrir was targeted by the regime, which probably organized the assaults to discredit the resistance (see Fathi, 2013). While these claims are open to speculation, security and insecurity in fact coexisted in Tahrir, and neither cancels out the other.

\section{Conclusion}

This analysis frames 'emancipatory power' in the post-liberal world by synthesizing Hannah Arendt's power conceptualization with feminist approaches to resistance and trust in collective action. This three-dimensional approach can be entertained as a theoretical foundation for the analysis of resistance in emancipatory security processes without abandoning emancipation or security. It links the individual to the collectivity while upholding differences. In addition, it also addresses the question of violence. Another potential of this discussion is that it challenges the 'victim-oriented' understanding in emancipatory security theory that renders individuals 'powerless' and waiting to be 'emancipated' (Spegele, 2002). If individuals and social groups are the agents of emancipation, the victim narrative should be dropped in favor of a local, critical agency. Surely, critical agency is agonistic and contested (Richmond, 2011b: 420), but also constructive, as the case of Tahrir illustrated.

Through this theoretical exercise and illustration of power-with in a moment of emancipation in Tahrir in 2011, three conclusions can be reached. First, one of the primary tasks of emancipatory security theory scholars should be to think about power in a way that is commensurate with the theory's analytical and normative objectives. Rather than avoiding power, it is necessary to enrich power understandings in emancipatory security theory. Recent works such as Nunes' are necessary, albeit incomplete without a theoretical substantiation of the power of resistance in the post-liberal world. In this sense, bodily performances of individuals that reconfigure the political space through emancipatory moments are crucial. Second, in thinking about power, it is important to acknowledge the ephemerality of such power in order to highlight the temporality of emancipatory projects. The objective of emancipatory power as the power of collective resistance is not to coerce and/or subordinate members and non-members of the social group, but to enable the presence of the resistance. This also requires rethinking emancipation in the post-liberal world. Finally, emancipatory power can easily disappear, and therefore destroy the social group, if members of the resistance start to impose a group identity over each other. One of the most important functions of trust through feminist empathy is its potential to maintain solidarity while preserving and upholding differences. To conclude, if emancipatory security theory aims to deliver on its promise to examine the security of 'real people in real places', its scope should be directed to 'people' and 'places'. In this way, the emancipatory power of collectivity consisting of individuals can be revealed while new dimensions of emancipatory security are explored. 


\section{Acknowledgements}

Some sections of this article were presented at the Political Science Association Annual Conference 2013 in Cardiff and the BISA Annual Conference 2013 in Birmingham. I would like to thank discussants in the panels, especially Christian Bueger for his suggestion for research on Hannah Arendt. In addition, I would like to thank Ken Booth for his encouragement to study the issue of power. My special thanks go to Athina Gkouti, Can Mutlu, and Uluç Karakaş for their comments and ideas, and to João Nunes and Nedim Karakayalı for their help during the research. None of them bear responsibility for any mistakes in the article.

\section{Funding}

This research received no specific grant from any funding agency in the public, commercial, or not-for-profit sectors.

\section{Notes}

1. Rejecting this claim, Booth himself argues that human security is 'an interesting idea' but 'has been appropriated by governments for their own use'; see Booth (2011: 477).

2. The scholars chosen for the analysis are those who explicitly study power in relation to emancipation. They offer a perspective about power. For this reason, Richard Wyn Jones (1999) is not included in the analysis.

3. See World Peace Through Technology (2011).

\section{References}

Agathangelou AM and Ling LHM (2005) Power and play through poisies: Reconstructing Self and Other in the 9/11 Commission Report. Millennium 33(3): 827-853.

Agathangelou AM and Soguk N (2013) Introduction: Rocking the Kasbah - Insurrectional politics, the 'Arab Streets', and global revolution in the 21st century. In: Agathangelou AM and Soguk N (eds) Arab Revolutions and World Transformations. London \& New York: Routledge, 1-8.

Allen A (1999) Power of Feminist Theory: Domination, Resistance, Solidarity. Oxford: Westview Press.

Amigot P and Pujal M (2009) On power, freedom, and gender: A fruitful tension between Foucault and feminism. Theory and Psychology 19(5): 646-669.

Anderson K (2011) The protestor. Time Magazine, 14 December.

Aradau C (2004) Security and the democratic scene: Desecuritization and emancipation. Journal of International Relations and Development 7(4): 388-413.

Aradau C (2008) Rethinking Trafficking of Women: Politics out of Security. Basingstoke: Palgrave Macmillan. Arendt H (1970) On Violence. London: Harvest.

Arendt H (1998) The Human Condition. Chicago, IL: University of Chicago Press.

Bailey ME (1993) Foucaldian feminism: Contesting bodies, sexuality and identity. In: Ramazanoğlu C (ed.) Up Against Foucault: Explorations of Some Tensions Between Foucault and Feminism. London: Routledge, 99-122.

Barnett M and Duvall R (2005) Power in global governance. In: Barnett M and Duvall R (eds) Power in Global Governance. Cambridge: Cambridge University Press, 1-32.

Basu S (2012) Security as emancipation: A feminist perspective. In: Tickner AJ and Sjoberg L (eds) Feminism and International Relations: Conversations About the Past, Present and Future. London: Routledge, 98-114.

Bauer P and Schweitzer B (2012) The Egyptian Revolution 2011: Mechanisms of violence and nonviolence. In: Preiss B and Brunner C (eds) Democracy in Crisis: The Dynamics of Civil Protest and Civil Resistance - Peace Report 2012. Vienna/Berlin: LIT-Verlag.

Benhabib S (2010) Introduction. In: Benhabib S (ed.) Politics in Dark Times: Encounters with Hannah Arendt. New York: Cambridge University Press, 1-14.

Bigo D (2011) Pierre Bourdieu and international relations: Power of practices, practices of power. International Political Sociology 5(2): 225-258. 
Bilgic A (2013) Rethinking Security in the Age of Migration: Trust and Emancipation in Europe. London: Routledge.

Booth K (1991) Security as emancipation. Review of International Studies 17(4): 313-326.

Booth K (2000) Three tyrannies. In: Dunne T and Wheeler N (eds) Human Rights in Global Politics. Cambridge: Cambridge University Press, 31-70.

Booth K (2005) Beyond critical security studies. In: Booth K (ed.) Critical Security Studies and World Politics. Boulder, CO: Lynne Rienner, 259-278.

Booth K (2007) Theory of World Security. Cambridge: Cambridge University Press.

Booth K (2011) Anchored in Tahrir Square. European Security 20(3): 473-479.

Booth K and Wheeler N (2008) The Security Dilemma: Fear, Cooperation, Trust. Basingstoke: Palgrave Macmillan.

Bordo S (1993a) Feminism, Foucault and the politics of the body. In: Ramazanoğlu C (ed.) Up Against Foucault: Explorations of Some Tensions Between Foucault and Feminism. London: Routledge, 179-202.

Bordo S (1993b) Unbearable Weight: Feminism, Western Culture and the Body. Berkeley, CA: University of California Press.

Browning CS and McDonald M (2013) The future of critical security studies: Ethics and the politics of security. European Journal of International Relations 19(2): 235-255.

Butler J (1990) Gender Trouble: Feminism and the Subversion of Identity. London: Routledge.

Butler J (2011) Bodies in alliance and the politics of the street. \#Occupy Los Angeles Reader 1-3. Available at: http://www.eipcp.net/transversal/1011/butler/en (accessed 3 February 2015).

Citizen Action Monitor (2011) Defiant, inspiring voices from Tahrir Square: 'This time we won't go home until we get all our rights'. 29 November. Available at: http://citizenactionmonitor.wordpress .com/2011/11/29/defiant-inspiring-voices-from-tahrir-square-this-time-we-wont-go-home-until-weget-all-our-rights/ (accessed 22 January 2015).

Cohen MA (2014) Genuine, non-calculative trust with calculative antecedents: Reconsidering Williamson on trust. Journal of Trust Research 4 (1): 44-56.

Confortini CC (2012) Reclaiming agency for social change: Feminism, international relations and the Women's International League for Peace and Freedom, 1945-75. In: Tickner AJ and Sjoberg L (eds) Feminism and International Relations: Conversations About the Past, Present and Future. London: Routledge, 22-47.

Cook S (2012) The Struggle for Egypt: From Nasser to Tahrir Square. Oxford: Oxford University Press.

Dietz G (2011) Going back to the source: Why do people trust each other? Journal of Trust Research 1(2): $215-222$.

Dolan FM (2005) The paradoxical liberty of bio-power: Hannah Arendt and Michel Foucault on modern politics. Philosophy \& Social Criticism 31(3): 369-380.

Duffield M (2010) The liberal way of development and the development-security impasse: Exploring the global life-chance divide. Security Dialogue 41(1): 53-76.

Dunne T and Wheeler N (2004) 'We the peoples': Contending discourses of security in human rights theory and practice. International Relations 18(1): 9-23.

Fathi Y (2013) The circle of hell: Inside Tahrir's mob sexual assault epidemic. Ahram Online, 21 February. Available at: http://english.ahram.org.eg/NewsContent/1/64/65115/Egypt/Politics-/The-circle-of-hellInside-Tahrirs-mob-assault-epid.aspx (accessed 22 January 2015).

Fierke K (1998) Changing Games, Changing Strategies: Critical Investigations in Security. Basingstoke: Palgrave.

Foucault M (1980) The History of Sexuality Volume 1: An Introduction. New York: Random House.

Fraser N (1989) Foucault on modern power: Empirical insights and normative confusions! In: Fraser N (ed.) Unruly Practices: Power, Discourse, and Gender in Contemporary Social Theory. Minneapolis, MN: University of Minnesota Press, 17-34.

Gordon N (2002) On visibility and power: An Arendtian corrective of Foucault. Human Studies 25(2): $125-145$.

Gregory D (2013) Tahrir: Politics, publics and performances of space. Middle East Critique 22(3): 235-246.

Guzzini S (2005) The concept of power: A constructivist analysis. Millennium 33(3): 495-521. 
Hearn J (2012) Theorizing Power. Basingstoke: Palgrave Macmillan.

Hirschkind C (2012) Interview with Alaa Abd al-Fattah, Tahrir Square, 12 pm, July 19th. Anthropological Quarterly 85(3): 917-926.

Hoffmann A (2006) Building Trust: Overcoming Suspicion in International Relations. New York: State University of New York Press.

Hollis M (1998) Trust Within Reason. Cambridge: Cambridge University Press.

Holsti KJ (1964) The concept of power in the study of international relations. Background 7(4): 179-194.

Hoogensen G and Rottem SV (2004) Gender identity and the subject of security. Security Dialogue 35(2): $155-171$.

Hoogensen G and Stuvøy K (2006) Gender, resistance and human security. Security Dialogue 37(2): 207-228.

Hynek N and Chandler D (2013) No emancipatory alternative, no critical security studies. Critical Studies on Security 1(1): 46-93.

Johansson-Nogués E (2013) Gendering the Arab Spring? Rights and (in)security of Tunisian, Egyptian and Libyan women. Security Dialogue 44(5-6): 393-409.

Jones K (1998) Trust as an effective attitude. Ethics 107(2): 4-25.

Kaltofen C (2013) Engaging Adorno: Critical security studies after emancipation. Security Dialogue 44(1): $37-51$.

Kateb G (2010) Fiction as poison. In: Berkowitz R, Katz J and Keenan T (eds) Thinking in Dark Times: Hannah Arendt on Ethics and Politics. New York: Fordham University Press, 29-41.

Khalil A (2011) Liberation Square: Inside the Egyptian Revolution and the Rebirth of a Nation. New York: St. Martin's.

Lally K (2011) Egypt women stand for equality in the square. Washington Post, 18 February.

Lebow RN (2005) Power, persuasion and justice. Millennium - Journal of International Studies 33(3): $551-581$.

Lukes S (2005) Power and the battle for hearts and minds. Millennium - Journal of International Studies 33(3): 477-493.

Mac Ginty R (2010) Hybrid peace: The interaction between top-down and bottom-up peace. Security Dialogue 41(4): 391-412.

Mac Ginty R and Richmond OP (2013) The local turn in peace building: A critical agenda for peace. Third World Quarterly 34(5): 763-783.

McDonald M (2012) Security, the Environment and Emancipation: Contestation over Environmental Change. London \& New York: Routledge.

McNay L (1992) Foucault and Feminism: Power, Gender and the Self. Boston, MA: Northeastern University Press.

Magdy Z (2011) Egypt: The two faces of liberation. Available at: https://www.opendemocracy.net/5050 /zainab-magdy/egypt-two-faces-of-liberation (accessed 3 February 2015).

Mellor N (2014) Who represents the revolutionaries? Examples from the Egyptian Revolution 2011. Mediterranean Politics 19(1): 82-98.

Muppidi H (2005) Colonial and postcolonial global governance. In: Barnett M and Duvall R (eds) Power in Global Governance. Cambridge: Cambridge University Press, 273-293.

Neal A (2010) Exceptionalism and the Politics of Counter-terrorism: Liberty, Security and the War on Terror. London: Routledge.

Neocleous M (2008) Critique of Security. Edinburgh: Edinburgh University Press.

Nielsen BB (2011) Trust in strategic alliances: Toward a co-evolutionary research model. Journal of Trust Research 1(2): 159-176.

Nunes J (2012) Reclaiming the political: Emancipation and critique in security studies. Security Dialogue 43(4): 345-361.

Nye JS (2004) Soft Power: The Means to Success in World Politics. Washington, DC: Public Affairs Press.

O'Neill O (2002) A Question of Trust. Cambridge: Cambridge University Press.

Owens P (2007) Between War and Politics: International Relations and the Thought of Hannah Arendt. New York: Oxford University Press.

Owens P (2012) Human security and the rise of the social. Review of International Studies 38(3): 547-567. 
Peoples C (2011) Security after emancipation? Critical theory, violence and resistance. Review of International Studies 37(3): 1113-1135.

Rashed MA (2011) The Egyptian Revolution. Anthropology Today 27(2): 22-27.

Richmond OP (2010) Resistance and the post-liberal peace. Millennium - Journal of International Studies 38(3): 665-692.

Richmond OP (2011a) Post-colonial hybridity and the return of human security. In: Chandler D and Hynek N (eds) Critical Perspectives on Human Security: Rethinking Emancipation and Power in International Relations. London: Routledge, 43-56.

Richmond OP (2011b) Critical agency, resistance and a post-colonial conflict. Cooperation and Conflict 46(4): 419-440.

Roberts D (2012) Human security, biopoverty and the possibility for emancipation. In: Chandler D and Hynek N (eds) Critical Perspectives on Human Security: Rethinking Emancipation and Power in International Relations. London: Routledge, 69-82.

Rosecrance R (2006) Power and international relations: The rise of China and its effects. International Studies Perspectives 7(4): 31-35.

Rosenberg T (2011) Revolution U: What Egypt learned from the students that overthrew Milosevic. Foreign Policy, 17 February. Available at: http:/www.foreignpolicy.com/articles/2011/02/16/revolution_u (accessed 22 January 2015).

Ruzicka J and Wheeler N (2010) The puzzle of trusting relationships in the Nuclear Non-Proliferation Treaty. International Affairs 86(1): 69-85.

Sampsonia Way (2011) The Egypt I didn't know. 8 February. Available at http://www.sampsoniaway.org /blog/2011/02/08/the-egypt-i-didnt-know/ (accessed 22 January 2015).

Schmidt BC (2005) Competing realist conceptions of power. Millennium - Journal of International Studies 33(3): 523-549.

Seligman AB (2000) Trust and civil society. In: Tankiss F and Passey A (eds) Trust and Civil Society. Basingstoke: Macmillan, 12-30.

Shepherd LJ (2010) Sex or gender? Bodies in world politics and why gender matters. In: Shepherd LJ (ed.) Gender Matters in Global Politics: A Feminist Introduction to International Relations. London: Routledge, 3-16.

Spegele RD (2002) Emancipatory international relations: Good news, bad news or no news at all? International Relations 16(3): 381-401.

Stern M (2006) Racism, sexism, classism, and much more: Reading security-identity in marginalized sites. In: Ackerly B, Stern M and True J (eds) Feminist Methodologies for International Relations. Cambridge: Cambridge University Press, 174-198.

Tadros M (2013) Egypt: The politics of sexual violence in protest spaces. 50.50, 4 July. Available at: https:// www.opendemocracy.net/5050/mariz-tadros/egypt-politics-of-sexual-violence-in-protest-spaces (accessed 22 January 2015).

Teti A (2012) The EU's first response to the 'Arab Spring': A critical discourse analysis of the Partnership for Democracy and Shared Prosperity. Mediterranean Politics 17(3): 266-284.

Tickner A (1992) Gender in International Relations: Feminist Perspectives on Achieving Global Security. New York: Columbia University Press.

Trombetta L (2013) More than just a battleground: Cairo's urban space during the 2011 protests. European Urban and Regional Studies 20(1): 139-144.

True J (2011) What is critical about critical theory revisited: The case of four international relations scholars and gender. In: Brincat S, Nunes J and Lima L (eds) Thirty Years of Critical Theory in World Politics. London: Routledge, 150-158.

Van Ham P (2010) Social Power in International Politics. London: Routledge.

van Munster R (2008) Review of Ken Booth, Theory of World Security. Cambridge Review of International Affairs 21(3): 437-450.

Wendt A (1999) Social Theory of International Politics. Cambridge: Cambridge University Press.

Wibben ATR (2011) Feminist politics in feminist security studies. Politics and Gender 7(4): 590-594. 
World Peace Through Technology (2011) Christians protecting Muslims in Egypt and reflections on a revolution. 4 February. Available at: http://peacetour.org/Egypt-revolution (accessed 22 January 2015).

Wyn Jones R (1999) Security, Strategy, Critical Theory. London: Lynne Rienner.

Ali Bilgic is Assistant Professor in the Department of International Relations, Bilkent University, Ankara. His research interests include critical approaches to security, feminist security studies, social movements, Turkey's foreign policy, and the European Union's external relations. He is the author of Rethinking Security in the Age of Migration: Trust and Emancipation in Europe (Routledge, 2013). His articles have appeared in Review of International Studies, International Relations, Eurasian Geography and Economics (co-authored), Journal of Southeast European and Black Sea Studies, Journal of Balkan and Near Eastern Studies and International Migration. 